\title{
Faktor-faktor yang Mempengaruhi Keberdayaan Anggota UPPKS DKI Jakarta menuju Kemandirian Usaha
}

\section{Factors Affecting the Empowerment of UPPKS Members DKI Jakarta towards Business Independency}

\author{
Lailatur Rohmah ${ }^{1}$, Pudji Muljono ${ }^{2}$, Ninuk Purbaningsih² dan Aida Vitayala² \\ ${ }^{1}$ Institut Ilmu Sosial dan Manajemen STIAMI Jakarta, Jl. Suprapto No.50A Jakarta Pusat 10530, Indonesia \\ ${ }^{2}$ Fakultas Ekologi Manusia Institut Pertanian Bogor
}

\begin{abstract}
Poverty is a major and complex problem, various efforts are made to alleviate poverty, but poverty rates do not decrease significantly, due to the low quality of human resources, which causes limited ability to improve welfare. Improving family welfare through UPPKS is a real contribution, and as a driving force for micro businesses in the community. So it needs to be maintained and developed, because it is a place of creativity to be independent and able to work creatively. The study aims to analyze the factors that influence the empowerment of UPPKS members. Data collection was conducted through interviews with 192 UPPKS members. Data analysis in this study included: (1) descriptive analysis in the form of frequency distribution with the help of SPSS and (2) PLS-SEM. The results showed that this hypothesis was tested by comparing tcount values and t-tables for each variable. The t-count value is greater than t-table (1.96) at the 0.05 level. The results of testing the hypothesis indicate that the factors that influence the empowerment of members are the characteristics of members $\left(X_{1}\right)$, the empowerment process $\left(X_{2}\right)$, the role of members $\left(X_{3}\right)$, and the support of the socio-cultural environment $\left(X_{4}\right)$. The empowerment of members is more dominantly influenced by the empowerment process $\left(\mathrm{X}_{2}\right)$ of 0.427. Positive influences indicate that the higher the characteristics of members, the empowerment process, and the support of the socio-cultural environment, the more empowerment will be. Negative influence is that the higher the role of the group, the lower the empowerment of the member. The empowerment of members significantly influences business independence by 0.354, meaning that the higher the empowerment of members, the greater the independence of the business.
\end{abstract}

Keywords: Member empowerment, business independence, UPPKS

\begin{abstract}
Abstrak
Kemiskinan merupakan masalah utama dan kompleks, berbagai upaya dilakukan untuk mengentaskan kemiskinan, tetapi angka kemiskinan tidak turun secara signifikan, disebabkan rendahnya kualitas sumber daya manusia, yang menyebabkan terbatasnya kemampuan dalam meningkatkan kesejahteraan. Peningkatan kesejahteraan keluarga yang melalui UPPKS merupakan kontribusi nyata, dan sebagai motor penggerak usaha mikro di masyarakat. Maka perlu dipertahankan dan dikembangkan, karena menjadi wadah kreativitas untuk mandiri dan mampu berkarya kreatif. Penelitian bertujuan menganalisis faktor-faktor yang memengaruhi keberdayaan anggota UPPKS. Pengumpulan data dilakukan melalui wawancara terhadap 192 anggota UPPKS. Analisis data dalam penelitian ini mencakup: (1) analisis deskriptif berupa distribusi frekuensi dengan bantuan SPSS dan (2) PLS-SEM. Hasil penelitian menunjukkan bahwa pengujian hipotesis ini dengan cara membandingkan nila t-hitung dan t-tabel untuk masing-masing peubah. Nilai t-hitung lebih besar dari t-tabel (1.96) pada taraf nyata 0.05. Hasil pengujian hipotesis menunjukkan bahwa faktor-faktor yang berpengaruh terhadap keberdayaan anggota adalah karakteristik anggota $\left(\mathrm{X}_{1}\right)$, proses pemberdayaan $\left(\mathrm{X}_{2}\right)$, Peran angota $\left(\mathrm{X}_{3}\right)$, dan dukungan lingkungan sosial budaya $\left(\mathrm{X}_{4}\right)$. Keberdayaan anggota lebih dominan dipengaruhi oleh proses pemberdayaan $\left(\mathrm{X}_{2}\right)$ sebesar 0.427 . Pengaruh positif menunjukkan bahwa semakin tinggi karakteristik anggota, proses pemberdayaan, dan dukungan lingkungan sosial budaya maka akan semakin meningkatkan keberdayaan. Pengaruh negatif bahwa semakin tinggi peran kelompok maka semakin rendah keberdayaan anggota tersebut. Keberdayaan anggota signifikan memengaruhi kemandirian usaha sebesar 0.354 artinya semakin tinggi tingkat keberdayaan anggota maka akan semakin meningkatkan kemandirian usaha.
\end{abstract}

Kata Kunci: Keberdayaan anggota, kemandirian usaha, UPPK

\footnotetext{
${ }^{1}$ Korespondensi penulis

E-mail: lailarahma1@yahoo.com
} 


\section{Pendahuluan}

Kemiskinan merupakan masalah utama dan kompleks, tetapi dengan tekad yang kuat, kemiskinan bisa ditekan atau diminimalkan. Berbagai upaya dilakukan untuk mengentaskan kemiskinan, tetapi angka kemiskinan tidak turun secara signifikan. Badan Pusat Statistik (BPS 2016) melaporkan bahwa jumlah penduduk miskin periode Maret 2016 sebanyak 28.01 juta jiwa (10.86 persen) baik di perkotaan maupun di pedesaan. Jika dibandingkan dengan periode September 2015 sebanyak 28.51 juta jiwa (11.13 persen), jadi angka penduduk miskin berkurang 0.50 juta jiwa.

Kemiskinan ini membentuk sebuah lingkaran setan yang sulit terputus. Hal ini disebabkan oleh rendahnya kualitas sumber daya manusia, yang akan menyebabkan terbatasnya kemampuan dalam meningkatkan kesejahteraan yang pada akhirnya menyebabkan manusia tetap miskin. Berdasarkan hasil pendataan keluarga yang dilakukan oleh BKKBN pada tahun 2010, jumlah keluarga di Indonesia tercatat sebanyak 62.4 juta keluarga atau sebesar 44.8 persen berada pada posisi keluarga miskin (Keluarga Pra Sejahtera dan Keluarga Sejahtera I) atau sekitar 27.9 juta keluarga miskin. Pada tahun 2012 jumlahnya meningkat menjadi 28.04 juta keluarga miskin. Masalah kemiskinan ini akan berdampak negatif terhadap stabilitas sosial dan masyarakat.

Peningkatan kesejahteraan keluarga yang melalui UPPKS ini merupakan kontribusi nyata, dan sebagai motor penggerak usaha mikro di masyarakat. Itu sebabnya UPPKS perlu dipertahankan dan dikembangkan, karena UPPKS yang didominasi ibu-ibu peserta KB itu, dinilai menjadi wadah kreativitas anggotanya untuk mandiri dan mampu berkarya kreatif. Hasil penelitian Wychille (2013) dan Margaret mengatakan bahwa Program UPPKS efektif dilakukan sesuai dengan harapan dan tujuan program yang menunjukkan terjadinya perubahan tingkat kesejahteraaan responden (57.38 persen) di Kabupaten Deli Serdang dan (86.56 persen) di Denpasar Barat. Namun permasalahan yang sering dihadapi oleh anggota UPPKS adalah tingkat kelangsungan hidup anggota atau kemandirian usahanya, dimana banyak usaha yang dilakukan oleh anggota tidak berkembang secara baik, bahkan banyak yang terputus usahanya. Hal ini perlu mendapat perhatian kita untuk mendorong anggota tersebut dapat mempunyai motivasi dan semangat melakukan usaha ekonomi produktifnya, memperoleh pengetahuan, dan ketrampilan untuk berwirausaha dan meningkatkan kemampuannya.

Ketidakmandiri usaha tersebut dikarenakan masih ketergantungan pada bantuan pemerintah dan sulitnya memperoleh modal dari bank, dimana modal merupakan masalah klasik yang masih dihadapi, terutama dari sumber-sumber pembiayaan formal. Lembaga perbankan sebagai salah satu sumber modal belum bisa mengatasi permasalahan yang dihadapi secara optimal, sehingga pelaku ekonomi produktif ini masih banyak menggunakan sumber pembiayaan informal seperti pedagang grosir, pedagang bahan baku dan rentenir. Bank-bank komersial dan lembaga formal lainnya belum mampu memenuhi kebutuhan kredit terutama karena persyaratan pinjaman dan kondisi usaha yang ada.

Peningkatan keberdayaan keluarga menjadi penting sehubungan dengan fakta adanya variasi kemampuan keluarga dalam pemenuhan kebutuhan, pelaksanaan fungsi, melalui pengelolaan sumberdaya yang dimiliki, serta kemampuan keluarga dalam pengelolaan masalah dan stress. Oleh sebab itu perlu diadakan upaya peningkatan pendapatan keluarga, dengan program UPPKS sangatlah penting keberadaannya. Usaha ini membina Ibu-Ibu rumah tangga yang termasuk golongan keluarga Pra S dan KS I agar mendapatkan penghasilan pribadi dengan memanfaatkan sumber daya alam di sekitar lingkungan tempat tinggalnya untuk diolah dan dikelola menjadi suatu usaha yang dapat menghasilkan pendapatan. Karena 
selain menambah pendapatan bagi keluarganya, penciptaan usaha melalui UPPKS juga dapat menciptakan lapangan pekerjaan bagi Ibu-Ibu, untuk itulah dibutuhkan pemberdayaan.

Rendahnya tingkat pendapatan anggota miskin tersebut berdampak terhadap rendahnya kesejahteraan mereka yang menempatkan mereka sebagai masyarakat yang tingkat kemandirian rendah. Dengan demikian guna membangun atau meningkatkan kesejahteraan anggota miskin tersebut, sangatlah perlu ditunjang oleh peran dari Pemerintah, salah satunya adalah dengan cara meningkatkan potensi keluarga (Hardiansyah 1997). Pemberdayaan keluarga di bidang ekonomi inilah merupakan salah satu usaha yang dapat dilakukan untuk dapat meningkatkan potensi keluarga dalam hal kesejahteraan. Pemberdayaan keluarga di bidang ekonomi berarti memberikan kesempatan kepada keluarga untuk dapat meningkatkan kemampuan dan ketrampilan untuk dapat memanfaatkan peluang kerja yang ada.
Kondisi ini mendorong dilakukan suatu penelitian yang bertujuan untuk menganalisis faktor-faktor apa saja yang mempengaruhi keberdayaan anggota dan faktor manakah yang paling dominan yang mempengaruhi keberdayaan anggota.

\section{Metode Penelitian}

Penelitian dilakukan di lima wilayah di DKI Jakarta. Penentuan lokasi penelitian dilakukan secara purposive yaitu pada daerah sentra usaha. Pengumpulan data dilakukan sejak bulan Februari hingga Mei 2017. Penentuan sampel pada penelitian ini dilakukan dengan beberapa langkah (multistage sampling). Langkah pertama, memilih secara sengaja wilayah yang menjadi sentral usaha. Langkah kedua pada setiap wilayah dipilih yang sudah masuk anggota AKU. Langkah ketiga dipilih anggota UPPKS yang diidentifikasi usahausaha yang aktif menjalankan usahanya sendiri. Selanjutnya ditentukan calon responden atau sampel dengan cara Proposive (Tabel 1).

Tabel 1 Proporsi sampel berdasarkan lokasi dan jumlah anggota

\begin{tabular}{lrrrrrrr}
\hline Keterangan & Jak & & \multicolumn{1}{c}{$\begin{array}{c}\text { Jak } \\
\text { sel }\end{array}$} & $\begin{array}{c}\text { Jak } \\
\text { tim }\end{array}$ & $\begin{array}{c}\text { Ja } \\
\text { kut }\end{array}$ & $\begin{array}{c}\text { Jak } \\
\text { bar }\end{array}$ & $\begin{array}{c}\text { Jum } \\
\text { lah }\end{array}$ \\
\hline Kecamatan & & 8 & 10 & 10 & 6 & 9 & 43 \\
Kelurahan & 40 & 56 & 59 & 30 & 53 & 238 \\
Kelompok & 155 & 199 & 192 & 153 & 170 & 869 \\
Anggota & 35 & 55 & 40 & 35 & 27 & $\mathbf{1 9 2}$ \\
\hline
\end{tabular}

\section{Teknik Analisis Data}

Data yang terkumpul dianalisis menggunakan statistik deskriptif dan analisis statistik inferensial. Peubah yang digunakan dalam penelitian ini adalah karakteristik anggota UPPKS, Proses pemberdayaan, peran kelompok, dukungan lingkungan sosial budaya, keberdayaan, dan kemandirian usaha. Analisis inferensial digunakan untuk menguji hipotesis dengan menggunakan Structural Equation Modeling (SEM) dengan bantuan software SmartPLS.3.0 M3 (Ghozali 2008). Adapun tahapannya sebagai berikut:
(1) Validitas, Hasil pengujian validitas konvergen berupa Outer loudings dan AVE. Outer loudings dilihat dari kriteria outer loudings >0.50;2) Realibilitas (cronbachs Alpha >0.60, composability Realibility $>0.60)$; 3) Pengujian Hipotesis, T-statistik > 1.96 (ttabel) (signifikan); 4) Evaluasi Model, kualitas model struktural dievaluasi melalui pengujian indeks pengukuran yaitu nilai RSquare.

\section{Hasil dan Pembahasan}

Hasil pengujian hipotesis menunjukkan bahwa faktor-faktor yang berpengaruh tehadap keberdayaan anggota adalah 
karakteristik anggota (X1), proses pemberdayaan (X2), Peran angota (X3), dan dukungan lingkungan sosial budaya (X4). Dalam hasil penelitian ini keberdayaan anggota lebih dominan dipengaruhi oleh proses pemberdayaan (X2) sebesar 0.427 bila dibandingkan dengan besar pengaruh karakteristik anggota (0.190), peran kelompok (-0.017), dan dukungan lingkungan sosial budaya sebesar 0.148. Pengaruh positif tersebut menunjukkan bahwa semakin tinggi karakteristik anggota, proses pemberdayaan, dan dukungan linkungan sosial budaya maka akan semakin meningkatkan keberdayaan anggota UPPKS. Pengaruh negatif, semakin tinggi peran kelompok maka semakin rendah keberdayaan anggota tersebut. Keberdayaan anggota signifikan mempengaruhi kemandirian usaha sebesar 0.354 artinya semakin tinggi keberdayaan anggota maka akan semakin meningkatkan kemandirian usaha (Gambar 1)

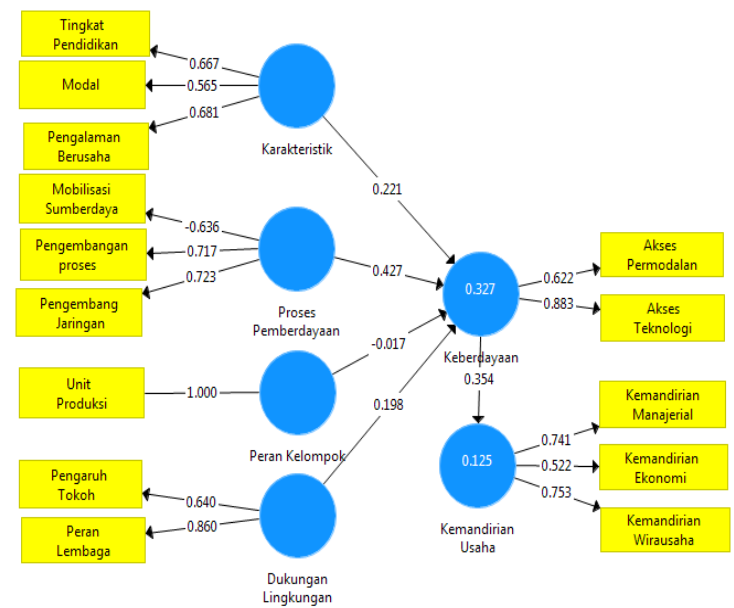

Gambar 1. Pendugaan parameter model struktural/hybrid model (standardized)

Tingkat keberdayaan anggota berada pada kategori sedang di empat indikator yaitu kemampuan mengakses permodalan, kemampuan mengakses informasi dan peluang pasar, kemampuan mengakses jaringan bisnis dan kemampuan mengakses sumberdaya, yang paling rendah dalam tingkat keberdayaan adalah kemampuan mengakses teknologi. Dari gambar 1 faktor yang paling signifikan memengaruhinya adalah proses pemberdayaan, dukungan lingkungan sosial budaya, dan karakteristik anggota. Proses pemberdayaan memberikan pengaruh yang paling signifikan dalam meningkatkan keberdayaan anggota, terutama dalam melakukan akses teknologi dan akses permodalan. Hal ini dapat menjelaskan bahwa proses pemberdayaan menjadi sangat penting dalam meningkatkan keberdayaan anggota. Pentingnya proses pemberdayaan terutama dalam mobilisasi sumberdaya secara seimbang, pengembangan dan gerakan perluasan proses, dan pengembangan jaringan dengan pihak ketiga, tentunya akan meningkatkan kemampuan anggota dalam mengakses teknologi, permodalan dan kemampuan mengakses jaringan bisnis.

Dukungan lingkungan sosial budaya yang paling signifikan memengaruhi tingkat keberdayaan anggota adalah pengaruh tokoh formal dan informal dan peran lembaga pendukung. Hal ini dapat menjelaskan bahwa dukungan lingkungan sosial budaya khususnya pengaruh tokoh formal, informal dan peran lembaga pendukung menjadi sangat penting dalam meningkatkan keberdayaan anggota. Pentingnya dukungan lingkungan sosial budaya, tentunya akan meningkatkan kemampuan anggota dalam mengakses teknologi, mengakses permodalan dan kemampuan mengakses jaringan bisnis.

Tingkat keberdayaan anggota selain dipengaruhi oleh proses pemberdayaan dan dukungan lingkungan sosial budaya juga dipengaruhi oleh karakteristik anggota. Karakteistik anggota yang paling signifikan 
memengaruhi keberdayaan adalah tingkat pendidikan, modal yang dimiliki, pengalaman berusaha. Hai ini dapat menjelaskan bahwa karakteristik anggota menjadi sangat penting dalam meningkatkan keberdayaan. Pentingnya tingkat Pendidikan, modal yang dimiliki, dan pengalaman berusaha, tentunya akan meningkatkan kemampuan anggota dalam mengakses teknologi, mengakses permodalan. Faktor-faktor yang memengaruhi keberdayaan anggota dianalisis menggunakan Struktural Equation Modeling (SEM) dengan bantuan program SmartPLS 3.0, yang mulanya dilakukan pengujian terhadap parameter dari model kerangka berpikir. Untuk melakukan pengujian model menggunakan prosedur dua tahap atau disebut two step approach (Latan 2013). Pertama melakukan pengujian Goodness of fit model, hasil pengolahan untuk pengujian goodness of fit dengan menggunakan pengujian alternative penggunaan indkator SEM yaitu kriteria SRMR (Standardized Root Mean Square Residual $)=0.102$; Exact fit criteria: d_ULS (the squared Euclidean distance) $=1.969$, d_GI (the geodesic distance) $=0.490$; d_G2 (the geodesic distance) $=0.462$; Chi-Square $\left(\mathrm{Chi}^{2}\right)=400.007$; dan NFI (Normed Fit Index) $=0.106$.

Tahap kedua dilakukan pengujian hipotesis teori, yatu berdasarkan gambar estimasi parameter model struktural antar peubah penelitian yang diuji. Tabel 2 menyajikan secara ringkas rangkuman hubungan kausal antar peubah-peubah laten dalam penelitian dan nila t-statistik sebagain uji statistik.

Tabel 2. Hasil estimasi model pengaruh peubah menggunakan standardized loading faktor

\begin{tabular}{|c|c|c|c|c|}
\hline No & Pengar & Variabel & $\begin{array}{l}\text { Standardized } \\
\text { loading faktor }\end{array}$ & $\begin{array}{l}\text { t-statistik } \\
>1.96\end{array}$ \\
\hline 1 & $\mathrm{X} 1 \rightarrow$ & Y1 & 0.221 & 3.400 Signifikan \\
\hline 2 & $\mathrm{X} 2 \rightarrow$ & Y1 & 0.427 & 3.454 Signifikan \\
\hline 3 & $\mathrm{X} 3 \rightarrow$ & Y1 & -0.017 & 0.293 Tidak Signifikan \\
\hline 4 & $\mathrm{X} 4 \rightarrow$ & $\mathrm{Y} 1$ & 0.198 & 3.094 Signifikan \\
\hline 5 & $\mathrm{Y} 1 \rightarrow$ & $\mathrm{Y} 2$ & 0.354 & 6.161 Signifikan \\
\hline
\end{tabular}

Hipotesis pertama yaitu karakteristik anggota (X1), proses pemberdayaan (X2), dan dukungan lingkungan sosial budaya (X4) berpengaruh nyata terhadap keberdayaan anggota (Y1). Namun variabel peran kelompok berpengaruh tidak nyata terhadap keberdayaan anggota. Pengujian hipotesis ini dengan cara membandingkan nila t-hitung dan t-tabel untuk masing-masing peubah. Nilai thitung lebih besar dari t-tabel (1.96) pada taraf nyata 0.05 . Secara matematik persamaan model struktural faktor-faktor yang memengaruhi terhadap tingkat keberdayaan anggota adalah:

$\mathrm{Y} 1=0.221 * \mathrm{X} 1+0.427 * \mathrm{X} 2+0.198 * \mathrm{X} 4, \mathrm{R}^{2}$ $=0.327 \ldots \ldots . . .($ persamaan 1$)$

Artinya secara simultan pengaruh ketiga peubah tersebut terhadap keberdayaan angota sebesar 0.33. Berarti keragaman data yang bisa dijelaskan oleh model tersebut sebesar 33 persen, sedangkan sisanya dijelaskan oleh peubah lain yang tidak ada dalam model dan error.

Pembahasan faktor-faktor yang memengaruhi tingkat keberdayaan anggota dan kemandirian usaha merujuk pada Gambar 1 diatas, akan diuraikan secara lebih terperinci.

\section{Pengaruh Karakteristik Anggota terhadap Keberdayaan Anggota}

Berdasarkan Gambar 1 terlihat bahwa besarnya koefisien parameter untuk variabel karakteristik (X1) sebesar 0.221 yang berarti terdapat pengaruh positif antara karakteristik (X1) terhadap (Y1) keberdayaan anggota. Atau dapat diinterpretasikan bahwa semakin baik karakteristik anggota, maka keberdayaan anggota semakin meningkat. Nilai t-statistik sebesar 3,400 signifikan. Dengan demikian 
hipotesis $\mathrm{H} 1$ dalam penelitian ini yang menyatakan bahwa karakteristik berpengaruh positif dan signifikan terhadap keberdayaan anggota diterima.

Karakteristik Anggota UPPKS yang berpengaruh nyata terhadap keberdayaan adalah tingkat pendidikan (X1.2), modal (X1.5), dan pengalaman berusaha (X1.8), Model pengukuran menunjukkan bahwa tingkat Pendidikan (0.667) lebih berperan penting dalam membentuk karakter anggota. Semakin tinggi tingkat pendidikannya, maka semakin mempengaruhi keberdayaan anggota.

Pengalaman berusaha (0.681) berperan penting dalam membentuk karakter anggota. Semakin tinggi pengalaman berusaha para anggota, maka semakin memengaruhi keberdayaan anggota. Pengalaman merupakan salah satu cara kepemilikan pengetahuan yang dialami seseorang dalam kurun waktu yang tidak ditentukan. Perry, Batstone dan Pulsarum (2003) menemukan pengalaman usaha memiliki pengaruh yang signifikan terhadap keberhasilan usaha kecil menengah. Jadi pengalaman usaha menjadi prediktor yang baik bagi pengambilan keputusan. Tingkat Pendidikan anggota di lima wilayah tidak menunjukkan ada perbedaan yang nyata dan termasuk kategori sedang. Sebagian besar responden berpendidikan SMA. sehingga dengan Pendidikan yang diraihkan menandakan bahwa anggota tersebut sudah pandai menemukan usaha apa yang sesuai dengan kebutuhan pasar. Modal yang dimiliki (0.565) berperan penting dalam membentuk karakter anggota. Semakin besar modal yang dimiliki, maka semakin memengaruhi keberdayaan anggota. Modal yang dimiliki yaitu banyaknya uang atau barang baik bersumber dari bantuan orang lain atau modal sendiri serta bagaimana pengelolaannya dan perkembangan modal tersebut. Modal awal yang dimiliki oleh anggota UPPKS ini sebagian besar masih rendah 74,36 persen yaitu dibawah 1 juta, ini juga sebagian dari pinjaman Sudin BKKBN/kantor KB. Hanya 5 persen yang bermodalkan lebih dari 4 juta rupiah, 20,64 persen bermodal 2 juta sampai pada 4 juta rupiah.

\section{Pengaruh Proses Pemberdayaan terhadap Keberdayaan Anggota}

Berdasarkan gambar 1 terlihat bahwa besarnya koefisien parameter untuk variabel proses pemberdayaan (X2) sebesar 0.427 yang berarti terdapat pengaruh positif antara proses pemberdayaan (X2) terhadap (Y1) keberdayaan. Atau dapat diinterpretasikan bahwa semakin tinggi proses pemberdayaan, maka keberdayaan anggota akan semakin meningkat. Nilai t-statistik sebesar 3.454 signifikan. Dengan demikian hipotesis H1 dalam penelitian ini yang menyatakan bahwa proses pemberdayaan berpengaruh positif dan signifikan terhadap keberdayaan anggota diterima.

Proses pemberdayaan yang berpengaruh nyata terhadap keberdayaan adalah mobilisasi sumberdaya secara seimbang (X2.4), pengembangan gerakan dan perluasan proses (X2.6), dan pengembangan jaringan dengan pihak ketiga (X2.7). Model pengukuran menunjukkan bahwa pengembangan gerakan dan perluasan proses (bobot nilai 0.717) lebih berperan penting dalam membentuk proses pemberdayaan. Semakin tinggi pengembangan gerakan dann perlusan proses, maka semakin memengaruhi keberdayaan anggota.

Model pengukuran yang pertama menunjukkan bahwa Pengembangan gerakan dan perluasan proses (0.717) berperan penting dalam proses pemberdayaan. Semakin tinggi pengembangan gerakan dan perluasan proses, maka semakin memengaruhi keberdayaan anggota. Dalam proses pemberdayaan ini seharusnya berpeluang bagus untuk para anggota, namun karena kurang maksimalnya para pengambil kebijakan khususnya dalam perluasan proses untuk pengembangan usaha para anggota. Pengembangan jaringan dengan pihak ketiga (0.723) berperan penting dalam proses pemberdayaan. Semakin tinggi pengembangan jaringan dengan pihak ketiga, 
maka semakin memengaruhi keberdayaan anggota. Pengembangan jaringan dengan pihak ketiga dilakukan dalam rangka memperluas lingkup pemberdayaan dengan melibatkan pihak-pihak yang dapat mendukung upaya pemberdayaan tersebut. Mobilisasi dan pemberian sumberdaya secara seimbang (0.636) berperan penting dalam proses pemberdayaan. Semakin tinggi mobilisasi dan pemberian sumberdaya secara seimbang, maka semakin memengaruhi keberdayaan anggota. Mobilisasi dan pemberian sumberdaya secara seimbang dilakukan dalam rangka memperluas lingkup pemberdayaan dengan melibatkan pihakpihak yang dapat mendukung upaya pemberdayaan tersebut.

\section{Pengaruh Peran Kelompok tehadap Keberdayaan Anggota}

Berdasarkan gambar 1 besarnya koefisien parameter untuk variabel peran kelompok (X3) sebesar -0.017 yang berarti terdapat pengaruh negatif antara peran kelompok (X3) terhadap (Y1) keberdayaan. Atau dapat diinterpretasikan bahwa semakin tinggi peran kelompok, maka keberdayaan anggota semakin menurun. Nilai t-statistik sebesar 0,293 tidak signifikan. Dengan demikian hipotesis H3 dalam penelitian ini yang menyatakan bahwa peran kelompok berpengaruh negatif dan tidak signifikan terhadap keberdayaan anggota ditolak.

Peran kelompok yang berpengaruh tidak nyata terhadap keberdayaan adalah peran sebagai unit produksi (X3.2). Peran kelompok sebagai unit produksi (1.000) berperan penting dalam peran kelompok. Semakin tinggi peran sebagai unit produksi, maka semakin memengaruhi keberdayaan anggota secara negatif. Peran sebagai unit produksi yaitu kelompok UPPKS merupakan kesatuan unit usaha untuk bertindak dalam meningkatkan produktivitas, mutu hasil produksi dan mencapai skala ekonomi yang lebih menguntungkan.

\section{Pengaruh Dukungan Lingkungan Sosial Budaya terhadap Keberdayaan Anggota}

Berdasarkan gambar 1 terlihat bahwa besarnya koefisien parameter untuk variabel dukungan lingkungan sosial budaya (X4) sebesar 0.198 yang berarti terdapat pengaruh positif antara dukungan lingkungan sosial budaya (X4) terhadap (Y1) keberdayaan. Atau dapat diinterpretasikan bahwa semakin besar dukungan lingkungan sosial budaya, maka keberdayaan anggota akan semakin meningkat. Nilai t-statistik sebesar 3,094 signifikan. Dengan demikian hipotesis H2 dalam penelitian ini yang menyatakan bahwa dukungan lingkungan sosial budaya berpengaruh positif dan signifikan terhadap keberdayaan anggota diterima.

Dukungan lingkungan sosial budaya yang berpengaruh nyata terhadap keberdayaan adalah pengaruh tokoh formal dan informal (X4.2) dan peran lembaga pendukung (X4.3). Model pengukuran menunjukkan bahwa peran lembaga pendukung ( 0.8760 lebih berperan penting dalam membentuk dukungan lingkungan sosial budaya. Semakin tinggi peran lembaga pendukung, maka semakin memengaruhi keberdayaan anggota. Peran lembaga pendukung adalah dukungan yang diberikan oleh suatu lembaga untuk ikut serta mensejahterakan anggota UPPKS. Pengaruh tokoh formal informal (0.640) berperan penting dalam dukungan lingkungan sosial budaya. Semakin tinggi pengaruh tokoh formal dan informal, maka semakin mempengaruhi keberdayaan anggota.

\section{Pengaruh Keberdayaan Anggota tehadap Kemandirian Usaha}

Berdasarkan gambar 1 terlihat besarnya koefisien parameter untuk variabel keberdayaan (Y1) sebesar 0.354 yang berarti terdapat pengaruh positif antara keberdayaan (Y1) terhadap (Y2) kemandirian usaha. Atau dapat diinterpretasikan bahwa semakin tinggi keberdayaan, maka kemandirian usaha anggota akan semakin meningkat. Nilai tstatistik sebesar 6,116 signifikan. Dengan demikian hipotesis H5 dalam penelitian ini yang menyatakan bahwa keberdayaan berpengaruh positif dan signifikan terhadap kemandirian usaha diterima. 
Keberdayaan anggota yang berpengaruh nyata terhadap kemandirian usaha adalah kemampuan mengakses permodalan (Y1.1), dan kemampuan mengakses teknologi (Y1.3). Model pengukuran menunjukkan bahwa kemampuan mengakses teknologi (0.883) lebih berperan penting dalam membentuk keberdayaan anggota. Semakin tinggi kemampuan mengakses teknologi, maka semakin memengaruhi kemandirian usaha. Akses teknologi, sains dan teknologi selain akan meningkatkan kuantitas barang dan jasa, juga akan meningkatkan kualitasnya sesuai dengan kebutuhan masyarakat. Perubahan teknologi akan membawa implikasi kepada perubahan kesejahteraan. Dijaman modern sekarang ini teknologi yang semakin canggih memang sangat diperlukan, namun dalam kenyataannya anggota UPPKS ini masih sangat rendah dalam mengakses teknologi. Kemampuan mengakses permodalan (bobot nilai 0.622) berperan penting dalam keberdayaan anggota. Semakin tinggi kemampuan mengakses permodalan, maka semakin memengaruhi kemandirian usaha. Akses Permodalan sangat penting untuk mengatasi hambatan ketiadaan/kekurangan modal usaha, sehingga kegiatan usaha dapat berjalan. Namun realitasnya sebagian besar anggota UPPKS belum mampu mengakses sumber modal yang disediakan melalui skim kredit di bank. Sudarwan dkk (2002) menemukan beberapa hambatan bagi masyarakat kecil untuk memperoleh kredit perbankkan adalah ketiadaan agunan dan ketidakmampuan dalam membuat proposal usaha. Akibatnya banyak diantara anggota lebih memilih meminjam pada rentenir, sehingga mereka terjebak pada tingkat suku bunga yang sangat tinggi. Kondisi ini dapat menggiring mereka pada situasi ketidakberdayaan.

Kemudahan memperoleh pinjaman modal merupakan motivasi utama anggota dalam mengikuti kegiatan kelompok. Adanya UPPKS ini sangat membatu para anggota untuk mendapatkan kredit yang murah dan mudah. Hal ini karena ketersediaan kredit yang mudah dan murah merupakan masalah umum yang banyak dihadapi oleh keluarga kurang mampu. Rendahnya akses terhadap bank bagi keluarga pedesaan disebabkan karena adanya persyaratan yang rumit disamping banyak ditemukan masalah uang pelepas dengan harga yang sangat tinggi. Kelompok UPPKS yang berhasil umumnya memiliki modal sendiri dari simpanan pokok, simpanan wajib, dan simpanan sukarela yang dihimpun dari setiap anggota selain modal dari pihak luar. Adanya anggota yang menunggak kredit, juga erat kaitannya dengan pembinaan dan kemampuan anggota yang menjalankan usaha secara efisien dan efektif. Kredit macet ini menyebabkan kelancaran untuk memperoleh pinjaman dari kelompok menjadi terhambat, sehingga timbul rasa iri dikalangan anggota yang belum mendapatkan fasilitas kredit.

\section{Simpulan}

Keberdayaan anggota UPPKS dipengaruhi oleh beberapa faktor antara lain karakteristik anggota, proses pemberdayaan, peran kelompok, dukungan lingkungan sosial budaya. Faktor yang paling dominan memengaruhi keberdayaan anggota adalah proses pemberdayaan. Begitu dengan keberdayaan memengaruhi kemandirian usaha.

\section{Daftar Pustaka}

Ghozali, I. 2008. Model persamaan structural, Konsep \& Aplikasinya dengan program Amos 16.0. Semarang. Badan Penerbit. UNDIP.

Hardinsyah dan Ujang Sumarwan. 1997. Pemberdayaan Ekonomi Keluarga. Makalah disampaikan pada Seminar Nasional IPADI, 25-26 November 1997, Cibogo, Bogor. IPB. Bogor.

Lody, H. 2012. Dampak program UPPKS dalam upaya peningkatan kesejahteraan ekonomi dalam menanggulangi kemiskinan di Kota Surakarta. USM. Surakarta.

Sudarwan D., Helmi H., dan Bahrin. 2002. Studi Dampak Proyek Pembinaan Peningkatan Pendapatan Petani dan 
Jurnal Penyuluhan, September 2019, Vol. 15 No. 2

Nelayan Kecil di Provinsi Wychille T.H. 2013. Efektivitas Program Bengkulu.Bengkulu: Universitas Usaha Peningkatan Pendapatan Bengkulu, Program Pascasarjana Keluarga Sejahtera (UPPKS) di Magister Manajemen Pendidikan. Kecamatan Denpasar Barat. Jurnal Undang-Undang nomor 52 Tahun 2009 Ekonomi Kuantitatif Terapan vol 6 tentang Perkembangan Kependudukan dan Pembangunan Keluarga 